\title{
Analisa Produktivitas pada UKM Dompet Kulit dengan Metode Objective Matriks (OMAX)
}

\author{
Marudut Sirait \\ Jurusan Teknik Industri, Fakultas Teknik, Universitas Brawijaya \\ Jl. MT Haryono 165, Malang, 65165, Indonesia \\ E-Mail :marudut@ub.ac.id
}

\begin{abstract}
ABSTRAK
Pengukuran tingkat produktivitas organisasi atau perusahaan penting dilakukan untuk mengevaluasi pencapaian dan melakukan perbaikan pada indikator produktivitas yang kurang baik. Tujuan penelitian ini adalah mengetahui tingkat produktivitas dari sebuah perusahaan dan mengevaluasi indikator yang kinerjanya paling buruk. Studi kasus dilakukan pada perusahaan dompet kulit yang sedang mengalami penurunan produktifitas selama periode tahun 2018, dimana jumlah produksi tidak mencapai target yang diharapkan sehingga harus menambah jam kerja/lembur untuk mencapai target. Dengan penambahan jam kerja, perusahaan mengeluarkan biaya lembur karyawan. Metode untuk mengukur tingkat produktifitas perusahaan adalah metode objective matriks atau OMAX dan penelitian ini mengacu pada langkah-langkah OMAX, yaitu menentukan kriteria produktivitas pada lini produksi, penentuan bobot, penentuan level-level pada objective matrix, perhitungan index produktivitas, dan analisa produktifitas dengan traffic light system. Pembobotan untuk menentukan bobot setiap indikator produktifitas dengan sistim linkert. Selanjutnya digunakan Traffic Light System (TLS) untuk pengelompokan level pencapaian indikator dan melakukan perbaikan untuk level indikator yang buruk. Hasil penelitian menunjukkan nilai rata-rata produktifitas keseluruhan pada tahun 2018 adalah 5,410. Indeks produktifitas tertinggi dicapai pada bulan Agustus sebesar 62,59\%. Dari traffic light sytem, diketahui bahwa indikator produktifitas yang paling buruk adalah pada faktor defect/cacat. Indikator produk cacat perlu perhatian khusus dalam rangka perbaikan untuk meningkatkan tingkat produktifitas perusahaan.
\end{abstract}

Kata Kunci: Objective Matrix, Produktifitas, Skala Linkert, Traffic Light System

\section{Productivity Analysis in Leather Wallet UKM by Objective Matrix Method (OMAX)}

\begin{abstract}
Measurement of productivity level of organization is important to evaluate its achievement and make improvements to the poor productivity indicator. The purpose of this study is to determine the productivity level of a company and evaluate the worst indicator performance. The case study conducted in a leather wallet company that was experiencing a decline in productivity during the period 2018, where the amount of production did not reach the expected target so that the company increased the working hours/overtime to reach the target. With the addition of working hours, the company incurred costs for employee overtime costs. To measure the level of productivity of the company, this study deployed the objective matrix method $(O M A X)$. The steps of this study refer to the OMAX method, by determining the criteria of productivity on the production line, determining the weights, determining the levels at objective matrix, productivity index calculation, and productivity analysis with a traffic light system. The weighting of each productivity indicator was based on the linkert system. The Traffic Light System (TLS) was used to classify the level of achievement of the indicator and made improvements to the level of a poor indicator. The results showed that the average value of overall productivity in 2018 was 5.410. The highest productivity index was achieved in August at $62.59 \%$. From the traffic light system, it can be seen that the worst indicator of productivity was the defect factor. The defect indicators of need special attention in order to improve the level of company productivity.
\end{abstract}


Keywords : Productivity, Objective Matrix, Linkert Scala, Traffic Light System.

\section{Pendahuluan}

Analisa dan pengukuran tingkat produktifitas sebuah perusahaan sangat penting untuk dilakukan dalam rangka mengevaluasi permasalahan yang menyebabkan produktifitas kurang baik dan selanjutnya menjadi dasar untuk perencanaan peningkatan produktifitas organisasi atau perusahaan. Oleh karena itu sangat perlu dilakukan pengukuran produktiftas untuk evaluasi terhadap kinerja sebuah perusahaan dan selanjutnya dilakukan perbaikan dalam rangka peningkatan kinerja perusahaan (Saragih \& Sirait, 2018).

UKM XYZ adalah sebuah perusahaan pembuatan dompet yang sedang berkembang yang terletak di Jawa Tengah. UKM XYZ perusahaan dengan sistem make to stock, yang produknya dikirim dan dipasarkan di berbagai kota di pulau Jawa, pulau Sulawesi, pulau Kalimantan dan juga daerah- daerah lain di seluruh Indonesia.

Kondisi perusahaan selama periode 2018 terjadi penurunan produksi dengan adanya perbedaan aktual produksi dengan target produksi. Artinya selama periode 2018 terjadi kekurangan produksi yang menyebabkan tingkat produktifitas menurun. Dari hasil indentifikasi awal, penyebab menurunya produktifitas disebabkan beberapa faktor, seperti jam kerja karyawan yang kurang jelas, banyaknya produk yang cacat, pengunaan energi listrik yang tinggi, pengunaan material yang tidak efisien. Oleh karena itu untuk mengidentikasi faktor mana yang mempunyai kotribusi yang paling besar terhadap penurunan produktifitas perusahaan, perlu dilakukan evaluasi secara menyeluruh dengan mengukur level produktifitas (Agustina \& Riana, 2011)

.Untuk mengetahui permasalahan sistem produksi yang menyebabkan tidak tercapainya target produksi, perlu dilakukan analisis produktifitas. Karena tingkat produktivitas yang baik menunjukkan bahwa perusahaan tersebut dalam kondisi sehat dan berkembang (Wahyuni \& Setiawan, 2017).
Banyak metode yang dilakukan untuk mengukur produktivitas seperti American Productivity Centre (Jalal \& Kusumawati, 2016) , Cob-Douglas (Dayal, 2015), metode PRISM (Purnomo \& Hadi, 2017), dan juga metode OMAX (Wahyuni \& Setiawan, 2017), (Ramadhani et al., 2018). Semua metode ini mempunyai kelebihan dan kekurangan. Oleh karena itu penentuan metode disesuaikan dengan permasalahan dan karakteristik dari setiap organisasi yang akan dikaji. Pada penelitian ini metode yang digunakan untuk menilai tingkat produktifitas perusahaan adalah dengan metode OMAX. Metode ini telah banyak digunakan dalam pengukuran produktifitas organisasi, karena metode ini sederhana dan mudah dipahami serta memberikan nilai produktifitas yang mudah dipahami (Gaspersz, 1998). Kelebihan lainnya adalah, dengan pengukuran produktifitas dengan metode OMAX dapat mendorong pengunaan sumber daya secara lebih effektif (Hernadewita, 2018).

Banyak penelitian-penelitian atau kajian untuk mengukur kinerj organisasi dengan menggunaka metode OMAX. Beberapa penelitian-penelitian sebelumnya yang telah dilakukan untuk mengukur produktifitas suatu organisasi/perusahaan dengan metode OMAX. Penelitian yang dilakukan oleh (Hamidah et al., 2013) yaitu mengukur tingkat produktifitas pada PT. Nippon Indosari Corpindo, Tbk Pasuruan dengan menggunakan Objective Matrix (OMAX). Hasil pengukuran menunjukkan skor tertinggi tingkat produktifitas terdapat pada kriteria pemakaian jam kerja (man hour) pada bulan Oktober 2012 dengan skor 9. Selanjutnya indikator penggunaan energy, bahan bakar, bahan baku mendapat nilai terendah yaitu 0 pada bulan November dan Desember 2012. Tetapi level indeks produktifitas total paling tinggi pada periode 2012 pada bulan Oktober 2012 dengan nilai $84.69 \%$ dan terendah dicapai pada bulan November dengan skor $-95.18 \%$. 
Penelitian lain juga melakukan pengukuran tingkat produktifitas pada sebuah perusahaan mesin-mesin pertanian. Hasil kajian menunjukkan tingkat produktifitas perusahaan selama periode pengukuran mengalami penurunan. Nilai indeks profitabilitas dari semua input adalah lebih kecil dari satu, sehingga perusahaan tersebut mengalami kerugian. Nilai indeks produktifitas memiliki nilai yang sama dengan indeks profitabilitas, sehingga ini menyebabkan tidak ada terjadi indeks perbaikan harga. Hal ini menandakan bahwa indeks perbaikan harga tidak berpengaruh terhadap profitabilitas perusahaan (Fithri \& Sari, 2015).

Walaupun penelitian produktifitas dengan pendekatan OMAX telah banyak dilakukan, tetapi penelitian produktifitas dengan metode OMAX berbeda dengan penelitian lainnya jika dilakukan pada perusahaan yang mempunyai karakteristik berbeda. Oleh karena itu penelitian ini mempunyai perbedaan dengan penelitian sebelumnya dengan mengambil kasus pada perusahaan kulit skala UKM dengan sifat make to stock. Juga, penelitian akan sangat memberikan banyak bermanfaat bagi perusahaan dalam rangka untuk mengetahui sejauh mana keberhasilan yang telah dicapai selama ini dan juga upaya melakukan perbaikan untuk meningkatkan kinerja perusahaan. Selain itu setiap perusahaan ingin lebih unggul dengan perusahaan-perusahaan kompetitornya dengan cara meningkatkan kinerja atau produktifitasnya pada setiap periodenya (Mail et al., 2018) .

\section{Metodologi}

Objective Matrix (OMAX) merupakan suatu alat dan metode untuk mengukur tingkat produktifitas parsial yang dibuat untuk mengevaluasi level produktifitas pada setiap bagian perusahaan dengan indikator produktifitas yang sesuai dengan keberadaan bagian tersebut (objective) (Felix \& Riggs, 1983). Dalam OMAX terdapat beberapa indikator-indikator produktifitas yang kemudian dimasukkan ke dalam suatu bentuk matriks OMAX. Dan setiap indikator saling berhubungan dengan indikator yang lain. Selanjutnya diperlukan pembobotan setiap indikator dalam pembentukan nilai pada table OMAX. Pada penelitian ini, pembobotan indikator dilakukan dengan sistim skala likert. Skala Likert yang dapat dipergunakan untuk mengukur sikap, pendapat, dan persepsi seseorang atau sekelompok orang tentang suatu gejala atau fenomena pendidikan (Budiaji, 2013); (Allen \& Seaman, 2007). Selajutnya untuk mengukur tingkat produktifitas setiap indikator, OMAX menggunakan sistim Traffic Light System (TLF) yang merupakan alat untuk mengidentifikasi baik buruknya pencapaian dari masing-masing indikator produktifitas pada periode tertentu. Dengan traffic light system, indikator dengan pencapain yang paling baik dan paling buruk dapat ditentukan. Selanjutnya penyusunan matrix OMAX dilakukan dengan langkah-langkah seperti dibawah ini

\subsection{Penentuan indikator kriteria produktifitas.}

Pada penelitian ini menggunakan 5 indikator produktifitas, yaitu indikator kriteria tenaga kerja (rasio antara jumlah produksi dengan jumlah tenaga kerja), indikator kriteria faktor material (rasio antara jumlah produksi dengan jumlah material), indikator faktor cacat (rasio antara jumlah produk cacat dengan jumlah produksi total), indikator jam kerja (rasio antara jumlah produksi dengan jumlah jam kerja), dan indikator faktor penggunaan energi (rasio antara jumlah pengunaan energi dengan jumlah produksi).

\subsection{Pembobotan}

Pembobotan dilakukan dengan pemberian kuesioner untuk pembobotan indikator produktifitas yang ditujukan kepada pemilik perusahaan dengan membandingkan setiap indikator produktifitas dan diberikan skala sesuai dengan tingkat kepentingan indikator tersebut dengan metode linkert seperti pada Tabel 1. 
Tabel 1. Penentuan bobot indikator dengan metode linkert

\begin{tabular}{clc}
\hline Skala & \multicolumn{1}{c}{ Keterangan } & $\begin{array}{c}\text { Pernyataan } \\
\text { Positif }\end{array}$ \\
\hline 1 & Sangat Baik & 5 \\
2 & Baik & 4 \\
3 & Cukup & 3 \\
4 & Tidang Baik & 2 \\
5 & Sangat Tidak Baik & 1 \\
\hline
\end{tabular}

\subsection{Pengisian level-level pada Objective Matrix (OMAX).}

Pengisisan baris performance dengan menggunakan hasil perhitungan nilai produktifitas dari periode yang akan diukur produktifitasnya. Nilai dari ratio setiap indikator produktifitas dimasukkan kedalam matrik OMAX.

\subsection{Perhitungan indeks produktifitas.}

Dari table OMAX diketahui value dari masing-masing indikator produktifitas dengan mengalikan antara nilai level dan bobot dari setiap indikator produktifitas setiap bulannya. Kemudian seluruh value tadi dijumlahkan sehingga didapat total value dari setiap indikator produktifitas. Selanjutnya nilai-nilai produktifitas diatas akan digunakan untuk menghitung indeks produktifitas setiap bulannya. Berikut ini merupakan rumus perhitungan indeks produktifitas untuk bulan Februari.

$\frac{\text { Productivitylndicotod(Februari)-Bosed Pefformonce(|anuari) }}{\text { Bosed Performonce (Januari) }} \times 100 \%$

\subsection{Analisis indeks produktifitas dengan traffic light system}

Sesuai dengan traffic light system pada tabel model OMAX, indikator produktifitas dinyatakan kinerjanya buruk apabila level pencapaian mencapai level 0 sampai dengan level 3 dan dinyatakan dengan warna merah. Jika indikator mencapai level 4-6 dinyatakan dengan warna kuning menunjukkan bahwa kondisi perusahaan cukup baik tapi perlu melakukan perbaikan. Selanjutnya, jika pencapaian indikator pada level 8-10 dinyatakan dengan warna hijau, menunjukkan produktifitas perusahaan dalam keadaan baik. Integrasi OMAX dengan TLS untuk mempermudah mengidentifikasi pencapaian indicator produktifitas (Adianto, 2014).

\section{Hasil dan Pembahasan}

\subsection{Perhitungan Rasio produktifitas}

Tabel 2 menjelaskan indikator produktifitas yang terpilih dari bulan januari sampai Desember tahun 2018. Indikor tersebut adalah indikator tenaga kerja (TK), penggunaan material (M), jumlah cacat (D) dan indikator pengunaan energy (E) dengan nilai ratio setiap indikator terdapat pada Tabel 2. Selanjutnya nilai-nilai rasio yang ada Tabel 2 dari setiap indikator produktifitas dimasukkan pada matrik OMAX.

Tabel 2. Ratio Indikator produktifitas

\begin{tabular}{lccccc}
\hline Periode & \multicolumn{5}{c}{ Ratio Indikator } \\
\cline { 2 - 6 } & $\begin{array}{c}\text { TK } \\
\text { Unit/or } \\
\text { ang }\end{array}$ & $\begin{array}{c}\mathrm{M} \\
\text { unit/ } \\
\mathrm{m}^{2}\end{array}$ & $\begin{array}{c}\mathrm{D} \\
(\%)\end{array}$ & $\begin{array}{c}\text { JK } \\
\text { (unit/jam }\end{array}$ & $\begin{array}{c}\mathrm{E} \\
\text { (rp/unit }\end{array}$ \\
\hline Januari & 6,88 & 3,18 & 2,40 & 99,95 & 235,12 \\
Februari & 6,97 & 3,20 & 1,79 & 99,51 & 217,97 \\
Maret & 6,94 & 3,29 & 2,26 & 100,13 & 237,24 \\
April & 6,99 & 3,26 & 3,10 & 100,81 & 240,65 \\
Mei & 7,01 & 3,21 & 2,75 & 100,97 & 239,47 \\
Juni & 6,72 & 3,28 & 1,53 & 97,72 & 224,71 \\
Juli & 6,59 & 3,23 & 1,59 & 93,91 & 233,17 \\
Agustus & 6,68 & 3,28 & 1,94 & 97,35 & 223,06 \\
September & 6,92 & 3,22 & 2,28 & 99,61 & 221,15 \\
Oktober & 6,84 & 3,31 & 2,24 & 99,55 & 231,37 \\
Nopember & 6,86 & 3,35 & 2,30 & 99,02 & 233,80 \\
Desember & 6,73 & 3,22 & 2,06 & 96,05 & 228,82 \\
\hline
\end{tabular}

\subsection{Pembobotan Indikator}

Berdasarkan hasil brainstorming dengan pihak manajemen perusahaan, bobot dari setiap indikator produktifitas perusahaan adalah sama pentingnya dalam pencapaian kinerja perusahaan. Sehingga diberi bobot 5. Sehingga bobot dari setiap indikator adalah sama yaitu $5 / 25 \times 100 \%=0,2$. Nilai bobot ini akan digunakan untuk menentukan nilai produktifitas setiap indiaktor dengan mengalikan dengan level performance setiap indikator produktifitas. 


\subsection{Penentuan nilai Level pada OMAX}

Nilai level produktifitas dihasilkan dari nilai ratio setiap indikator. Penentuan level produktifitas perusahaan dilakukan dengan menggunakan model OMAX. Model ini terdiri dari 10 level, dimana level 10 merupakan hasil tertinggi yang akan dicapai sesuai dengan perkiraan waktu yang sudah ditentukan, selanjutnya level 3 adalah level rata-rata tahun sebelumnya, dan terakhir adalah level 0 , pada level ini pencapaian nilai produktifitas terburuk tahun sebelumnya. Selanjutnya untuk penetuan level yang lain, maka dilakukan interpolasi. Untuk penentuan nilai produktifitas dari level di interval 3 sampai 10 dilakukan dengan melakukan interpolasi dari nilai level 10 dan nilai level 3 . Sedangkan untuk nilai level interval 0 sampai 3 dilakukan dengan interpolasi antara nilai level 3 dan nilai level 0 . Tabel 3 menunjukkan pencapaian nilai pada level 0 , level 3 , dan level 10

Tabel 3. Pencapain Level

\begin{tabular}{lccc}
\hline \multirow{2}{*}{ Kriteria } & \multicolumn{3}{c}{ Pencapaian } \\
\cline { 2 - 4 } & Level 10 & Level 3 & Level 0 \\
\hline TK & 7,0 & 6,74 & 6,44 \\
M & 3,40 & 3,20 & 3,0 \\
D & 0 & 2,5 & 3,5 \\
JK & 101,64 & 96,70 & 92,86 \\
E & 224.51 & 235.41 & 247.25 \\
\hline
\end{tabular}

\subsection{Perhitungan Nilai dan Index Produktifitas}

Nilai produktifitas dihasilkan dari level performance dikali dengan bobot setiap indikator. Sedangkan nilai index produktifitas dihasilan dari nilai produktifitas dengan mengunakan rumus 1. Hasil nilai produktifitas dan index produktifitas selama periode 2018 dapat dilihat pada Tabel 4. Indeks produktifitas (IP) tertinggi berada pada bulan Agustus dengan nilai 62.59 dengan nilai produktifitas 5,294. Sebaliknya nilai IP paling kecil terjadi pada bulan Juli dengan nilai IP sebesar -48,448 dengan nilai produktifitas 3,256 .

Sebagai tambahan, nilai semua indikator produktifitas secara keselurahan adalah 64,924 dan nilai rata-rata produktifitasnya sebesar 5,410. Dengan nilai
5,410 kondisi produktifitas terdapat pada warna kuning, yaitu level 4-7, yang artinya kondisi perusahaan dalam kondisi cukup dan perlu perbaikan untuk mencapai target level lebih baik, yaitu level 8-10.

Tabel 4. Indeks Produktivitas

\begin{tabular}{ccc}
\hline Periode & $\begin{array}{c}\text { Nilai } \\
\text { Produktifitas }\end{array}$ & $\begin{array}{c}\text { Indeks } \\
\text { Produktifitas } \\
(\%)\end{array}$ \\
\hline Januari & 4,8 & - \\
Februari & 6,85 & 42.708 \\
Maret & 5,708 & -16.671 \\
April & 5,284 & -7.428 \\
Mei & 5,316 & 0.605 \\
Juni & 6,316 & 18.811 \\
Juli & 3,256 & -48.448 \\
Agustus & 5,294 & 62.59 \\
September & 6,478 & 22.36 \\
Oktober & 5,818 & -10.188 \\
November & 5,704 & -1.959 \\
Desember & 4,1 & -0.281 \\
\hline Nilai & 64,924 & \\
Produktifitas & & \\
\hline Rata Rata Nilai & 5,410 & \\
Produktifitas & & \\
\hline
\end{tabular}

\subsection{Analisa Traffic Light System}

Tabel 6. Indikator produktifitas dengan Traffic Light System

\begin{tabular}{lccccc}
\hline & \multicolumn{5}{c}{ Indikator Produktifitas } \\
\cline { 2 - 6 } Periode & TK & MT & D & JK & E \\
\hline Januari & 7 & 2.66 & 3.27 & 7.89 & 3.18 \\
Februari & 9.25 & 3 & 5 & 7 & 10 \\
Maret & 8.5 & 6 & 3.66 & 7.85 & 2.53 \\
April & 9.75 & 5 & 1.18 & 8.82 & 1.67 \\
Mei & 10 & 3.33 & 2.24 & 9.05 & 1.96 \\
Juni & 2.8 & 6 & 5.69 & 7.22 & 9.87 \\
Juli & 1.5 & 4 & 5.53 & 0.82 & 4.43 \\
Agustus & 2.4 & 6 & 4.55 & 3.52 & 10 \\
September & 8 & 3.66 & 3.61 & 7.12 & 10 \\
Oktober & 5.75 & 7 & 3.72 & 7.04 & 5.58 \\
November & 6.33 & 8.33 & 3.55 & 6.28 & 4.03 \\
Desember & 2.9 & 3.66 & 4.22 & 2.49 & 7.23 \\
\hline
\end{tabular}

Analisa TLS digunan untuk mengidentifikasi tigkat pencapain kinerja perusahaan dengan mengunan simbol warna 
hijau, kuning dan merah. Tabel 6 menunjukkan pencapain indikator kriteria secara parsial dengan penilaian traffic light system. Warna hijau menunjukkan bahwa kriteria produktifitas telah mencapai target produktifitas yang diiginkan dengan rentang nilai $8-10$, warna kuning menunjukkan nilai produktifitas belum mencapai target produktifitas yang ingin dicapai, dengan rentang nilai 4-7, dan terakhir kriteria produktifitas warna merah menunjukkan bahwa tingkat pencapain produktifitas belum tercapai dengan rentang nilai produktifitas antara 0 sampai 3. Hasil analisis menunjukkan bahwa indikator cacat produk mempunyai kontribusi pada penurun produktifitas perusahaan yang ditunjukkan dengan banyaknya nilai/indicator warna merah selama produksi 2018. Banyaknya jumlah cacat pada produk pembuatan dompet kulit, seperti sobek, pengeleman yang tidak sempurna, dan jahitan yang tidak rapi sehingga perlu dilakukan rework atau waste menimbulkan cost/biaya untuk proses membutuhkan biaya tambahan dan waktu kerja yang meningkat. Implikasinya, tingkat produktifitas perusahaan menurun secara signifikan. Oleh karena itu perlu dilakukan usaha-usaha untuk mengurangi cacat produk untuk meningkatkan produktifitas pada periode berikutnya dengan cara perbaikan proses produksi, meningkatkan kualitas karyawan, dan membentuk tim pengendalian kualitas. Diharapkan dengan perbaikanperbaikan pada indikator yang merah, terutama pada indikator cacat produk dapat meningkatkan produktifitas, profit dan performance dari UKM dompet kulit pada periode berikutnya.

\section{Kesimpulan}

Secara umum indikator yang mempengaruhi produktifitas perusahaan adalah indikator tenaga kerja, indikator penggunaan bahan baku, indikator produk cacat/defect, dan indikator pengunaan energi. Nilai rata-rata produktifitas keseluruhan pada tahun 2018 berdasarkan kelima indikator adalah 5,410. Dari OMAX tingkat produktifitas perusahaan berada level 4-7 dengan lampu warna kuning yang artinya produktifitas perusahaan berada dalam kategori cukup teapi masih perlu melakuan perbaikan untuk meningkatkan kinerja untuk mencapai kinerja ideal, yaitu pada level 8-level 10. Tingkat indeks produktifitas terbesar berada pada bulan Agustus dengan kenaikan indeks produktifitas sebesar 62,59\%. Sebaliknya penurunan indek produktifitas terjadi pada bulan Juli sebesar $-48.448 \%$. Pencapaian dari semua indikator produktifitas, indikator produk cacat atau defect memiliki kontribusi terbesar dari menurunnya tingkat produktifitas perusahaan. Itu ditunjukkan dengan banyak lampu warna merah pada indikator produk cacat selama periode tahun 2018. Oleh karena itu diperlukan langkah strategis untuk perbaikan dan mengurangi produk cacat dari proses produksi.

\section{Daftar Pustaka}

Adianto. (2014). Analisis Pengukuran Kinerja Perusahaan dengan Metode Performance Prism dan Scoring Objective Matrix (OMAX) pada PT. BPAS. ANALISIS PENGUKURAN KINERJA PERUSAHAAN DENGAN METODE PERFORMANCE PRISM DAN SCORING OBJECTIVE MATRIX (OMAX) PADA PT. BPAS.

Agustina, F., \& Riana, N. A. (2011). Analisis Produktivitas dengan Metode Objective Matrix (OMAX) di PT. X. In Jurnal Teknik dan Manajemen Industri.

Allen, I. E., \& Seaman, C. A. (2007). Likert scales and data analyses. In Quality Progress.

Budiaji, W. (2013). Skala Pengukuran dan Jumlah Respon Skala Likert. Jurnal Ilmu Pertanian Dan Perikanan, 2(2), 127-133. http://umbidharma.org/jipp

Dayal, V. (2015). The Cobb-Douglas Function. Spriger, New Delhi. https://doi.org/10.1007/978-81-3222340-5_6

Felix, G. H., \& Riggs, J. L. (1983). Productivity measurement by objectives. National Productivity Review. 
https://doi.org/10.1002/npr.4040020407

Fithri, P., \& Sari, R. Y. (2015). Analisis Pengukuran Produktivitas Perusahaan Alsintan CV. Cherry Sarana Agro. Jurnal Optimasi Sistem Industri, 14(1), 138-155.

https://doi.org/10.25077/josi.v14.n1.p13 8-155.2015

Gaspersz, V. (1998). Manajemen Produktivitas Total Strategi Oeningkatan Produktivitas Bisnis Global. Gramedia Pustaka Utama, Jakarta.

Hamidah, N. H., Deoranto, P., \& Astuti, R. (2013). Analisis Produktivitas Menggunakan Metode Objective Matrix (OMAX): Studi Kasus pada Bagin Produksi Sari Roti PT Nippon Indosari Corpindo, TBK Pasuruan. Jurnal Teknologi Pertanian Analisis Produktivitas, 14(3), 215-222.

Hernadewita. (2018). an Analysis on Enhance Productivity Through Objectve Matrix (Omax) Method on Manufacturing Line. International Journal of Modern Research in Engineering and Technology (IJMRET) Www.Ijmret.Org.

Jalal, A., \& Kusumawati, H. (2016). ANALISIS PRODUKTIVITAS PEMBUATAN KAIN GREY DENGAN PENDEKATAN METODE AMERICAN PRODUCTIVITY CENTER DAN COBB-DOUGLAS. Teknoin, 22(4), 239-251. https://doi.org/10.20885/teknoin.vol22.is s4.art 1

Mail, A., Alisyahbana, T., Saleh, A., Malik, R., \& Ibrahim, I. (2018). ANALISIS PRODUKTIVITAS DENGAN METODE OBJEKTIVE MATRIX (OMAX) PADA CV. BINTANG JAYA. Journal of Industrial Engineering Management. https://doi.org/10.33536/jiem.v3i2.234

Purnomo, C. A., \& Hadi, Y. (2017). PENGUKURAN KINERJA UMKM MENGGUNAKAN PERFORMANCE PRISM. SPEKTRUM INDUSTRI, 15(2), 121. https://doi.org/10.12928/si.v15i2.7550

Ramadhani, S. N., Prihandoko, A. C., \&
Adiwijaya, N. O. (2018). Sistem Informasi Pengukuran Produktivitas Hotel di Kabupaten Jember Menggunakan Metode OMAX (Objective Matrix) dan AHP (Analytical Hierarchy Process) (Studi Kasus Hotel Istana). BERKALA SAINSTEK. https://doi.org/10.19184/bst.v6i1.7555

Saragih, R., \& Sirait, M. (2018). ANALISIS PRODUKTIVITAS HASIL PRODUKSI GULA DENGAN METODE OBJECTIVE MATRIX ( OMAX ) DI PG KEBON AGUNG. Jurnal Rekayasa Dan Manajemen Sistim Industri, 7(2), 96-107.

Wahyuni, H. C., \& Setiawan, S. (2017). Implementasi Metode Objective Matrix (OMAX) Untuk Pengukuran Produktivitas Pada PT.ABC. PROZIMA (Productivity, Optimization and Manufacturing System Engineering). https://doi.org/10.21070/prozima.v1i1.7 02 